\title{
An enigmatic diapriid wasp (Insecta, Hymenoptera) from French Cretaceous amber
}

\author{
Malvina LAK \\ Université Rennes I, UMR CNRS 6118 Géosciences, \\ campus de Beaulieu bât. 15, 263 avenue du Général Leclerc, \\ F-35042 Rennes cedex (France) \\ malvina.lak@univ-rennes1.fr
}

André NEL

Muséum national d'Histoire naturelle, CNRS UMR 7205,

Département Systématique et Évolution,

case postale 50, 57 rue Cuvier, F-75231 Paris cedex 05 (France)

anel@mnhn.fr

KEY WORDS

Insecta,

Hymenoptera,

Diaprioidea

Diapriidae, amber,

Cretaceous,

Cenomanian,

Charente,

microtomography,

X-ray synchrotron.

MOTS CLÉS

Insecta,

Hymenoptera,

Diaprioidea,

Diapriidae,

ambre,

Crétacé,

Cénomanien,

Charente,

France,

microtomographie, rayons X synchrotron.
Lak M. \& Nel A. 2009. - An enigmatic diapriid wasp (Insecta, Hymenoptera) from French Cretaceous amber. Geodiversitas 31 (1): 137-144.

\begin{abstract}
A new wasp of uncertain affinities within the family Diapriidae is described after a single specimen preserved in mid-Cretaceous (Early Cenomanian) amber from France. The possible relationships of the new fossil within the family and related groups are discussed. The fossil was studied using phase contrast X-ray synchrotron imaging, a powerful tool recently used in palaeontology studies. Several other organisms (arthropods, plants remains and microorganisms as well) were also found in the same piece of amber, notably aquatic organisms, which supply informations on the habitat of this specimen.

\section{RÉSUMÉ}

Une guêpe Diapriidae (Insecta, Hymenoptera) énigmatique de l'ambre crétacé français.

Une guêpe d'affinités incertaines au sein des Diapriidae, est décrite à partir d'un spécimen unique préservé dans l'ambre crétacé moyen (Cénomanien basal) de France. Les relations possibles du nouveau fossile au sein de la famille et des groupes proches sont discutées. Le fossile a pu être étudié grâce à l'imagerie par rayonnement $\mathrm{X}$ synchrotron en contraste de phase, un outil puissant récemment employé en paléontologie. Plusieurs autres organismes (arthropodes, restes végétaux mais aussi micro-organismes) ont été trouvés dans le même morceau d'ambre, et notamment des organismes aquatiques qui nous fournissent des informations quant à l'habitat de ce specimen.
\end{abstract}




\section{INTRODUCTION}

Diapriidae Haliday, 1833 is a quite diverse family of small endoparasitic wasps mainly of Diptera, but also of ants and staphylinid beetles (Loiacono 1987; Masner 1993). They are found worldwide, although they are mostly abundant in the southern hemisphere, and live in wet forests and marshes near water or in the soil.

Only a few Diapriidae are known from the Cretaceous period, the fossil record of the family being significant since the Eocene only (for list and discussion on the Mesozoic taxa that have been included into the Diapriidae, see Perrichot $\& \mathrm{Nel}$ 2009). Several hundreds of hymenopteran inclusions were already recorded from mid-Cretaceous amber from Charentes (Schlüter 1978; Perrichot et al. 2007a), however including only a single specimen of Diapriidae in the subfamily Belytinae Haliday, 1833 (Perrichot \& Nel 2009).

Here we describe a diapriid wasp from the Lower Cenomanian amber of Charentes, in southwestern France. It lacks crucial characters for an accurate placement among the known subfamilies, but remains important as it is one of the very few Cretaceous records of the family. The synecological assemblage observed with this wasp seems to be congruent with an estuarian-like habitat.

\section{MATERIAL AND METHODS}

The specimen is preserved in a piece of amber collected in 2005 during road works that have allowed a temporary access to an Early Cenomanian deposit at La Buzinie near Champniers, in the Angoulême area (Charente, SW France) (Perrichot et al. 2007b). The fossil resin was deposited in a marine facies of glauconitic limestones rich in the oyster Rhynchostreon suborbiculatum (Lamarck, 1801) and containing some pieces of lignitic wood perforated by Teredo Linnaeus, 1758. Stratigraphically, this facies was located in the mid part of the Lower Cenomanian series, corresponding to the B2 lithological subunit (sensu Néraudeau et al. 1997). It is interbedded in a transgressive sequence between, at the base, coastal glauconitic sands with reptile remains (Vullo et al. 2007) and, above, deeper marine clay.

The amber pieces collected in the B2 subunit from La Buzinie are rare, rather large (several centimetres in diameter) and more or less opaque. So, the specimen (which is preserved with several other inclusions) has been detected and 3D-reconstructed using propagation phase contrast X-ray synchrotron imaging on the beamline ID19 of the European Synchrotron Radiation Facility (ESRF) of Grenoble. This nondestructive technique is recently applied in imaging of fossil inclusions in amber (Tafforeau et al. 2006; Lak et al. 2008a) although it is developed for about 10 years (Snigirev et al. 1995; Cloetens et al. 1996). The detailed protocol for application of X-ray microradiography and microtomography to the detection and reconstruction of amber inclusions is given in Lak et al. (2008b). This particular specimen has been scanned with a pixel size of $1.4 \mu \mathrm{m}$ using a multilayer monochromator, the energy was set at $20.5 \mathrm{keV}$ and the propagation distance was $100 \mathrm{~mm}$. Because the field of view obtained with such parameters was too small vertically, two scans were required. For each of them, 1500 projections were recorded on $180^{\circ}$ with $0.5 \mathrm{~s}$ of exposure time per radiograph. In accordance with what was previously suggested in Lak et al. (2008a), raw and segmented data are available on request to authors for the present, as additional information to the specimen deposited in the Muséum national d'Histoire naturelle (MNHN), Paris. A project of free online access from a database at ESRF is currently in progress.

In the description below we follow the body and wing venation terminology of Huber \& Sharkey (1993).

\section{SYSTEMATIC PALAEONTOLOGY}

\author{
Superfamily Diaprioidea HaLidaY, 1833 \\ sensu Sharkey (2007) \\ Family DiAPRIIDAE Haliday, 1833 \\ Subfamily incertae sedis \\ Genus and species indet. \\ (Figs 1;2)
}

MATERIAL EXAMINED. - Specimen MNHN BUZ 2.6 (well-preserved specimen in opaque amber) from the Lenglet collection, deposited in the MNHN. 
LOCALITY AND HORIZON. — La Buzinie at Champniers, near Angoulême, Charente, SW France. Mid-Cretaceous, Lower Cenomanian, B2 lithological subunit (Néraudeau et al. 1997; Perrichot et al. 2007b).

DiAGNOSIS. - Labrum concealed under clypeus; malar sulcus present; antennae 11-segmented, inserted high above clypeus on a low shelf, with toruli facing upwards; scape rather short, 0.5 times as long as head height in lateral view; pedicel ovoid; a well-defined epomia present; notauli distinct; no false spur on fore tibia; petiole less than twice as long as broad, longitudinally sculptured; metasoma ellipsoidal, not narrowly pointed at apex; second metasomal tergite the longest; second metasomal sternite the longest; no split between laterosternite and ventral sternite present on sternite 2 , and neither on following sternites.

\section{DESCRIPTION}

Setation not visible by preservation. Head: hypognathous, transversely ovoid; eyes large; ocelli equidistant, ocellar triangle situated in ocular zone; labrum concealed under clypeus; malar sulcus present; mandibles short, bidentate, with outer side curved. Maxillary palpi five-segmented. Antenna with nine flagellomeres, not clubbed, inserted high above clypeus (at a distance equal to the length of scape) on a transverse shelf of low elevation; toruli facing upwards; scape 1.3 times longer than wide and 0.5 times as long as head height in lateral view; pedicel slightly shorter than first flagellomere, ovoid, broadest at about its mid length; first flagellomere conical, following ones cylindrical, slightly shorter and not increasing gradually in size, narrowed basally; apical one ovoid; no antennomere can be defined as a (male) modified sex segment.

Mesosoma: a well-defined epomia present, pronotum medially (including cervix) distinctly shorter than mesoscutum; mesoscutum with notauli forming two deep crenulate furrows converging but not touching posteriorly; ornamentation of scutellum partly visible, anterior scutellar pit apparently bifoveate, lateral and posterior scutellar pits not visible; epicnemial pit apparently absent; sternaulus well developed; metanotum densely carinate. Wings unknown, only basal part of three veins visible. Hind coxa much thicker than fore and mid ones; fore and mid legs thin, hind leg thicker; tibiae broadened at about four-fifths of length; tibial spur formula 1-2-2, a long and curved spur on fore tibia, no false spur; mid and hind tibial spurs shorter and straight.

Metasoma: gaster ellipsoidal, not narrowly pointed at apex, with six visible tergites; petiole short, subcylindrical, less than twice as long as broad, longitudinally carinate; petiole-gaster junction not clearly visible for the presence of gas bubbles around this zone but the large tergite 2 seems to cover the apex of petiole at least laterally; second metasomal tergite very large and the longest, tergite 2 about 14 times as long as tergum 3 as seen from the side; second sternite the longest, distinctly longer than third, four very short sternites visible distal of second sternite; a ridge between sternite 2 and lateral margin of tergite 2; no split between laterosternite and ventral sternite present on sternite 2, and neither on following sternites; genital appendages not clearly visible although a structure that could be interpreted as a sting is visible (possibly a female?).

\section{Measurements (in mm)}

Head length 0.22 , height 0.23 ; eye diameter 0.14 , scape length 0.08 , pedicel length 0.07 ; mesosomal length 0.44 , height 0.3 ; length of legs: fore femur 0.17 , tibia 0.14 , tarsi 0.15 , mid femur 0.17 , tibia 0.14 , tarsi 0.21 , hind femur 0.21 , tibia 0.30 , tarsi 0.34 ; metasomal length 0.55 , width 0.28 ; petiole length 0.10 ; metasomal tergum 2 length 0.37 .

\section{DISCUSSION}

Although incompletely preserved, the new fossil can be confidently attributed to the Diaprioidea (= Diapriidae + Monomachidae Ashmead, $1902+$ Maamingidae Masner, Naumann \& Austin, 2001) sensu Sharkey (2007), based on the first metasomal segment in the form of a cylindrical petiole and the insertion of antennae on a facial shelf. This last character is considered by Early et al. (2001a, b) as a putative synapomorphy of the (Diapriidae + Maamingidae), and less evidently the Monomachidae. A same grouping of these three families was also found by Dowton \& Austin (2001) in a combined analysis of morphological and molecular characters of apocritans, suggesting diaprioids to be a coherent 


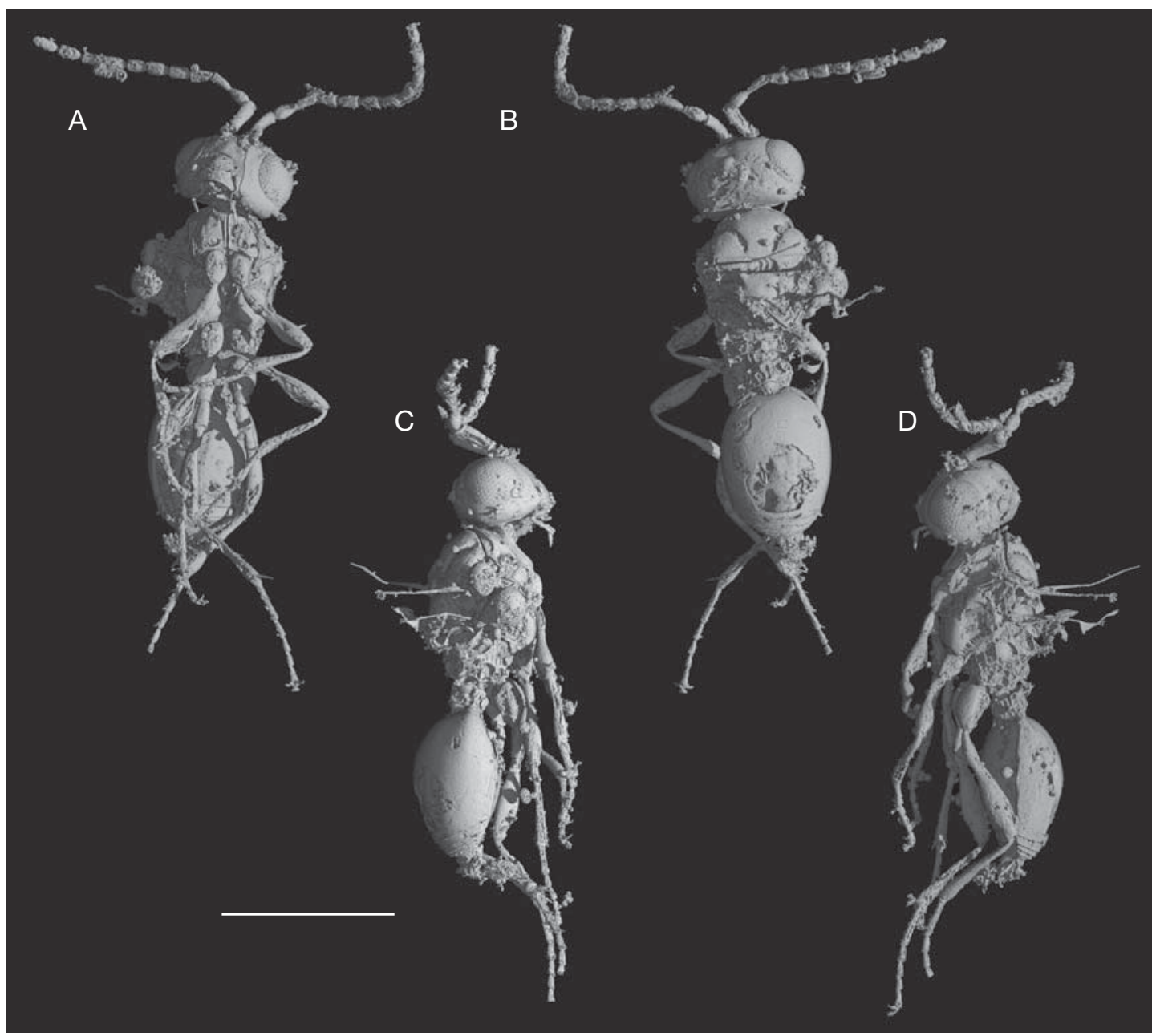

FIG. 1. - New Diapriidae in French Cretaceous amber, specimen MNHN BUZ 2.6; general habitus in ventral (A), dorsal (B), right lateral (C) and left lateral (D) views, as reconstructed using phase contrast X-ray synchrotron imaging. Scale bar: $500 \mu \mathrm{m}$.

group distinct from the Proctotrupoidea Latreille, 1802. Some Proctotrupoidea and even Cynipoidea Latreille, 1802 also display a low facial antennal shelf (Proctotrupidae, Figitidae Thomson, 1862), but in these groups the antennae have a higher number of antennal segments and are usually inserted lower on the face, and the structure and arrangement of the first and second metasomal segments are clearly different, thus precluding the placement of the new fossil in these families. Among the Diaprioidea, the fossil strongly differs from both Maamingidae and Monomachidae in a putative specialized character that can be found in the Diapriidae: Diapriinae and Belytinae, viz. the second metasomal tergite and sternite the longest. A similar metasomal structure can be found in some other wasp families (Heloridae Foerster, 1856, etc.) not related to the Diaprioidea, which do not have a similar facial shelf however. Thus the unique combination of a facial shelf, the first metasomal tergite and sternite fused to form a cylindrical petiole, and the second tergite and sternite the longest, strongly indicate affinities of the new fossil with the Diapriidae. 

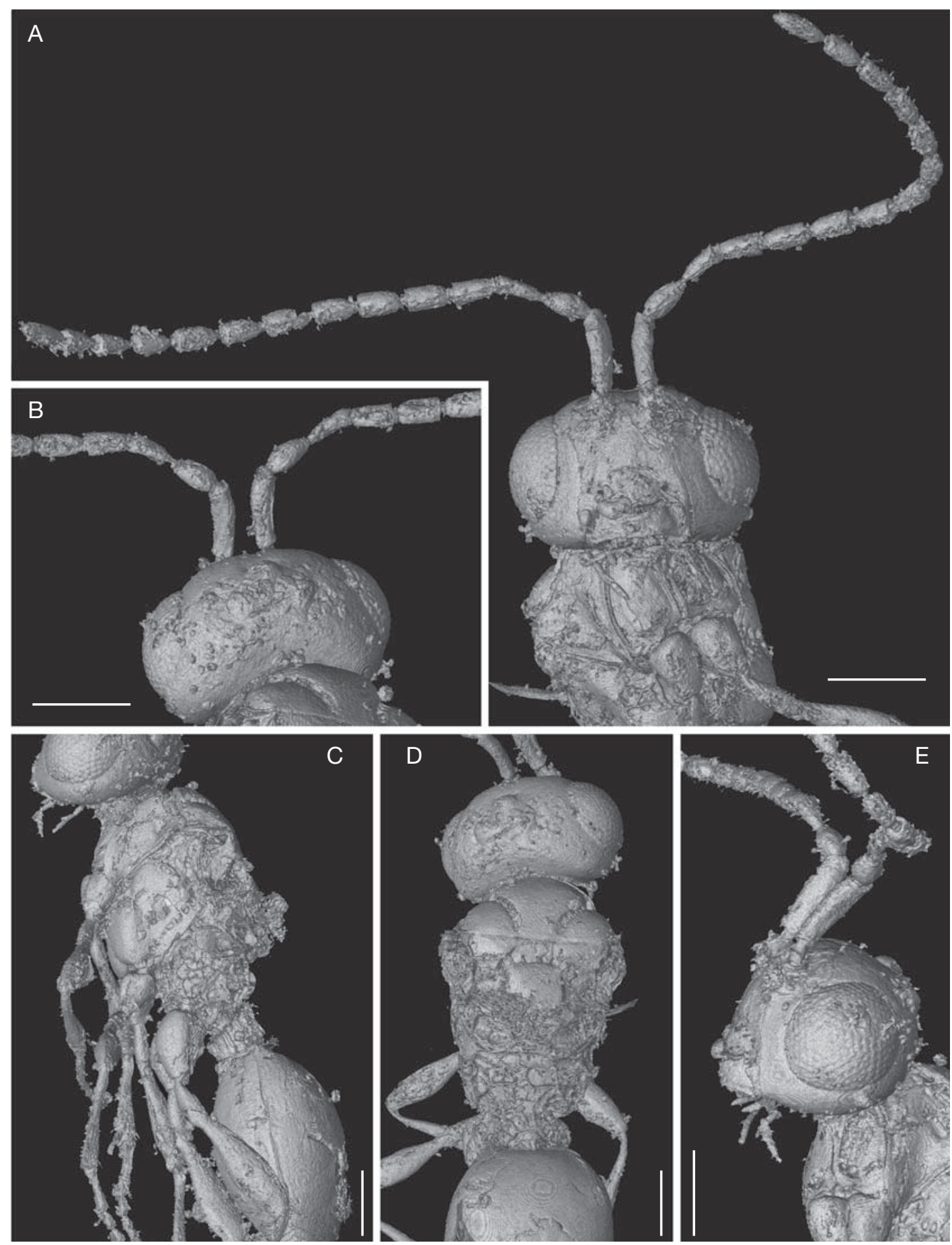

FIG. 2. - Detailed views of the new Diapriidae in French Cretaceous amber (voxel 1.4 $\mu \mathrm{m}$ ): A, B, head and antennae in frontal and dorsal views; C, D, Mesosoma represented with wings removed in left lateral and dorsal views; E, head in left lateral view. Scale bars: $100 \mu \mathrm{m}$. 
Among the four known subfamilies, our specimen can be excluded from Ismarinae, according to Masner (1961, 1976, 1993) and Naumann (1988), because of the presence of notauli and the absence of a false spur on fore tibia. After the key to diapriid subfamilies of Yoder (2007), the characters antennae inserted on a shelf, and at some distance from the clypeus also exclude the Ismarinae. Finally the Ismarinae have no notauli and an antennal formula 14-15, unlike our fossil. The character second metasomal sternite the longest, distinctly longer than third excludes affinities with the Ambositrinae. The absence of any split between laterosternite and ventral sternite on sternite 2, and neither on the following sternites, plus perhaps the petiole-gaster junction apparently completely covered by tergite 2 , are characters that would contradict affinities with the Belytinae. But this is not clearly evident on the reconstruction of the fossil, as the tergite 2 seems to cover the anterior margin of the petiole only laterally (see dorsal and right lateral views on Figures 1B, C; 2C, D). Most of the diapriids are sexually dimorphic, with the main difference being expressed in the number of antennal segments. The new fossil has only 11 antennomeres and a similar number can be found mostly in both male or female Diapriinae, but some female Belytinae have a reduced number of antennomeres as well. As the genital appendages of the fossil are mostly obscured by debris that could not be removed in the reconstruction, a determination of the sex cannot be ascertained. Also the phylogeny and classification of the Diapriidae has to be clarified. Masner \& Garcia (2002) considered that the Diapriinae appear, at least by our present knowledge, as a paraphyletic group, which is the main problem to attribute this fossil to this subfamily as there is no defined apomorphy that would support this assumption. Thus any tentative placement is not conclusive enough and we prefer to let the fossil unnamed as incertae sedis within the Diapriidae until its sex and affinity can be better stated by the hopeful discovery of additional material. Nevertheless, this fossil constitutes a rare, interesting record of a Cretaceous Diaprioidea that strengthens the current issue relative to the heterogeneity of the character information for diapriids and higher "proctotrupoids" (see Ronquist 1999; Early et al. 2001a; Masner \& Garcia 2002). Indeed, these recent works have demonstrated that the traditional suite of synapomorphies for diapriids is more homoplastic across higher proctotrupoids and diaprioids than previously believed.

Synecologically, the fossil is preserved in a piece of amber that is relatively rich in macroinclusions (at least 15 well-preserved arthropods and five plant remains) as well as in microinclusions (mainly freshwater testate amoebae) (V. Girard pers. comm.). The piece of amber is translucent enough to see five of the macroinclusions but for the other ones, phase contrast X-ray imaging was necessary. Among arthropods, Diptera seems to be the most abundant taxa (notably represented by Dolichopodidae [Microphorites Hennig, 1971] and Psychodidae [Lak et al., 2008]), but some other Hymenoptera, Blattodea and a decapod Tanaidacea have been also found.

Such a fossil assemblage may be of interest regarding that modern diapriids wasps have a large geographic distribution as well as diversified habitat (Masner \& Garcia 2002). The association with other arthropods like the tanaidacean crustacean, usually associated to marine or coastal environment (Gutu \& Sieg 1999), as well as marine microinclusions such as sponge spicules (Girard et al. 2008) provides us with some supplementary informations. Indeed the tanaidacean fossil might have been trapped as a dead body, but its quite good preservation may indicate a short transport and proximity between aquatic environment and the resin-producing tree. Sponge spicules seem to be in favor of a littoral or estuarian environment. The modern diapriids live in the southern hemisphere in wet forests and marshes near water or in the soil. Some even live in the intertidal zone of emerged lands. The association between the diapriid, the tanaid, the different Diptera, Hymenoptera, and Blattodea, indicates that the resin flowed on a soil located nearby to the water, trapping both aerial insects and aquatic crustacean. According to these syn- and autoecological informations, it is very likely that this diapriid lived in a littoral forest environment. 


\section{Acknowledgements}

Many thanks to Thierry Lenglet who found and gave us the specimen sutdied here. We are also greatly indebted to Paul Tafforeau for his help during the experiments and his technical advices, and to the European Synchrotron Radiation Facility of Grenoble team for its welcome and the technical support. Finally, we want to thank Didier Néraudeau and Vincent Perrichot for constructive advice about this manuscript. This work is supported by the Agence nationale de la Recherche (ANR), project AMBRACE no. BLAN07-1-184190.

\section{REFERENCES}

Cloetens P., Barrett R., Baruchel J., Guigay J.-P. \& SCHLENKER M. 1996. — Phase objects in synchrotron radiation hard X-ray imaging. Journal of Physics D: Applied Physics 29: 133-146.

DowTOn M. \& Austin A. D. 2001. - Simultaneous analysis of $16 \mathrm{~S}, 28 \mathrm{~S}, \mathrm{COI}$ and morphology in the Hymenoptera: Apocrita - evolutionary transitions among parasitic wasps. Biological Journal of the Linnean Society 74: 87-111.

Early J.W., Masner L., Naumann I. D. \& Austin A. D. 2001a. - Maamingidae, a new family of proctotrupoid wasp (Insecta: Hymenoptera) from New Zealand. Invertebrate Taxonomy 15: 341-352.

Early J.W., Masner L., Naumann I.D. \& Austin A. D. 2001b. - Maamingidae, a new family of Proctotrupoidea unique to New Zealand, in MeliKa G. \& THuróczy C. (eds), Parasitic wasps: evolution, systematics, biodiversity and biological control. International symposium: "Parasitic Hymenoptera: Taxonomy and Biological Control”, 14-17 May 2001, Köszeg, Hungary, Agroinform Kiadó \& Nyomda KFT, Budapest: 13-18.

Girard V., Schmidt A. R., Saint Martin S., Struwe S., Perrichot V., Saint Martin J.-P., Grosheny D., Breton G. \& Néraudeau D. 2008. - Evidence for marine microfossils from amber. Proceedings of the National Academy of Sciences of the United States of America 105 (45): 17426-17429.

GuTu M. \& SiEg J. 1999. — Ordre des Tanaïdacés (Tanaidacea Hansen, 1885). Mémoires de l'Institut océanographique de Monaco 19: 351-389.

Huber J. T. \& SHARKEY M. J. 1993. — Structure, in GOULET H. \& HUBER J. T. (eds), Hymenoptera of the World: an Identification Guide to Families. Research Branch Agriculture Canada Publication, Ottawa: 13-59.

LaK M., Néraudeau D., Nel A., Cloetens P., PerriCHOT V. \& TAFFOREAU P. 2008a. — Phase contrast
X-ray synchrotron imaging: opening access to fossil inclusions in opaque amber. Microscopy and Microanalysis 14: 251-259.

Lak M., Azar D., Nel A., Néraudeau D. \& TafFOREAU P. 2008b. - The oldest representative of the Trichomyiinae (Diptera: Psychodidae) from the Lower Cenomanian French amber studied with phase contrast synchrotron X-ray imaging. Invertebrate Systematics 22: 471-478.

LOIACONO M. S. 1987. — Un nuevo diaprido (Hymenoptera) parasitoide de larvas de Acromyrmex ambiguus (Emery) (Hymenoptera, Formicidae) en el Uruguay. Revista de la Sociedad Entomologica Argentina 44: 129-136.

MASNER L. 1961. - Ambositrinae, a new subfamily of Diapriidae from Madagascar and Central Africa (Hymenoptera: Proctotrupoidea). Mémoires de l'Institut scientifique de Madagascar (E) 12: 289-295.

MASNER L. 1976. - A revision of the Ismarinae of the New World (Proctotrupoidea: Diapriidae). The Canadian Entomologist 108: 1243-1266.

MASNER L. 1993. - Superfamily Proctotrupoidea, in GOuleT H. \& Huber J. T. (eds), Hymenoptera of the World: an Identification Guide to Families. Research Branch Agriculture Canada Publication, Ottawa: 537-557.

Masner L. \& García J. L. 2002. - The genera of Diapriinae (Hymenoptera: Diapriidae) in the New World. Bulletin of the American Museum of Natural History 268: 1-138.

NAUmANn I. D. 1988. - Ambositrinae (Insecta: Hymenoptera: Diapriidae). Fauna of New Zealand 15: $1-168$.

Néraudeau D., Thierry J. \& Moreau P. 1997. Variations of echinoids biodiversity during the Cenomanian-Early Turonian transgressive episode in Charentes (France). Bulletin de la Société géologique de France 168: 51-61.

Perrichot V. \& Nel A. 2009. - A new belytine wasp in Cretaceous amber from France (Hymenoptera: Diapriidae). Alavesia 2: 203-209.

Perrichot V., Néraudeau D., Nel A. \& De Plö̈g G. 2007a. - A reassessment of the Cretaceous amber deposits from France and their palaeontological significance. African Invertebrates 48: 213-227.

Perrichot V., Nel A. \& Néraudeau D. 2007b. Schizopterid bugs (Insecta: Heteroptera) in midCretaceous ambers from France and Myanmar. Palaeontology 50: 1367-1374.

RONQUIST F. 1999. - Phylogeny, classification and evolution of the Cynipoidea. Zoologica Scripta 28: 139-164.

SCHLÜTER T. 1978. — Zur Systematik und Palökologie harzkonservieter Arthropoda einer Taphozönose aus dem Cenomanium von NW-Frankreich. Berliner Geowissenschlaftliche Abhandlungen (A) 9: 1-150. 
Sharkey M. J. 2007. - Phylogeny and classification of Hymenoptera. Zootaxa 1668: 521-548.

Snigirev A., Snigireva V., Kohn S., KuZnetsov S. \& SCHELOKOV I. 1995. - On the possibilities of X-ray phase contrast microimaging by coherent high-energy synchrotron radiation. Review of Scientific Instruments 66: 5486-5492.

Tafforeau P., Boistel R., Boller E., Bravin A., Brunet M., Chaimanee Y., Cloetens P., Feist M., HosZOWSKa J., JAEGer J.-J., KaY R. F., LAZZARI V., Marivaux L., Nel A., Nemoz C., Thibault X., Vignaud P. \& Zabler S. 2006. - Applications of X-ray synchrotron microtomography for nondestructive 3D studies of paleontological specimens. Applied Physics A: Material Science \& Processing 83: 195-202.

Vullo R., Néraudeau D. \& Lenglet T. 2007. Dinosaur teeth from the Cenomanian of Charentes, western France: evidence for a mixed LaurasianGondwanan assemblage. Journal of Vertebrate Paleontology 27: 931-943.

Yoder M. 2007. - The Diapriidae. Version 12.2008. http://www.diapriid.org/projects/1/public/clave/ show/381 (last accessed the 3 March 2009).

Submitted on 4 January 2008; accepted on 2 March 2009. 